\title{
Ecophysiological and biochemical responses of saltbush subjected to salinity ${ }^{1}$
}

\author{
Luiz Fernando Ganassali de Oliveira Junior ${ }^{2}$, Fabrício de Oliveira Reis ${ }^{3}$, \\ Jailson Lara Fagundes ${ }^{2}$, Paulo Roberto Gagliardi², Lucas Fonseca Menezes Oliveira ${ }^{2}$
}

\section{ABSTRACT}

Saltbush, a halophyte species tolerant to salt stress, is an excellent material for the identification of physiological and biochemical mechanisms involved in the resistance to salinity. This study aimed at evaluating the ecophysiological and biochemical responses of saltbush plants at the concentrations of $0 \mathrm{mM}, 150 \mathrm{mM}, 300 \mathrm{mM}, 450 \mathrm{mM}$ and $600 \mathrm{mM}$ of $\mathrm{NaCl}$. Biometry, gas exchange and relative content of chlorophyll and proline in the leaves were measured. Plants presented growth stimulation mainly at the levels of $0 \mathrm{mM}, 150 \mathrm{mM}$ and $300 \mathrm{mM}$ of $\mathrm{NaCl}$. Regarding gas exchange, plants showed variation in the photosynthetic rate and stomatal regulation, with a small increase in leaf transpiration. Salinity did not significantly alter the chlorophyll contents, but induced an increase in proline contents in all $\mathrm{NaCl}$ levels, demonstrating a growth maintenance capacity and indicating the occurrence of osmotic adjustment.

KEY-WORDS: Atriplex numulária; gas exchange; proline.

\section{INTRODUCTION}

Soil salinization is a serious problem in the Brazilian semiarid region, due to a climate characterized by high evapotranspiration and low rainfall rates. Salinity can interfere with the development of crops, reducing plant production and yield to uneconomical levels (Souza et al. 2000, Leal et al. 2008).

Halophytes are the only plants that can live in soil with high salt concentration (Taiz \& Zeiger 2013). Species of the Atriplex genus are considered authentic halophytes, since they are characterized by high tolerance to drought and soil salinity, and

\section{RESUMO}

Respostas ecofisiológicas e

bioquímicas de erva-sal submetida a salinidade

A erva-sal, uma halófita tolerante ao estresse salino, constitui excelente material para a identificação de mecanismos fisiológicos e bioquímicos envolvidos na resistência a salinidade. Objetivou-se avaliar as respostas ecofisiológicas e bioquímicas de plantas de erva-sal, nas concentrações de $0 \mathrm{mM}, 150 \mathrm{mM}, 300 \mathrm{mM}$, $450 \mathrm{mM}$ e $600 \mathrm{mM}$ de $\mathrm{NaCl}$. A biometria, trocas gasosas e teor relativo de clorofilas e de prolina nas folhas foram mensurados. As plantas apresentaram estímulo de crescimento principalmente nos níveis de $0 \mathrm{mM}, 150 \mathrm{mM}$ e $300 \mathrm{mM}$ de $\mathrm{NaCl}$. Quanto às trocas gasosas, houve variação na taxa fotossintética e regulação estomática, gerando um pequeno aumento na transpiração foliar. A salinidade não alterou significativamente os teores de clorofilas, mas induziu incremento nos teores de prolina em todos os níveis de $\mathrm{NaCl}$, demonstrando capacidade de manutenção do crescimento e evidenciando ocorrência de ajustamento osmótico.

PALAVRAS-CHAVE: Atriplex numulária; trocas gasosas; prolina.

are able to complete their life cycle under these environmental constraints (Porto et al. 2000).

Atriplex nummularia Lindl., commonly known as saltbush, is a halophyte known for its tolerance to salt and water stress. Additionally, saltbush produces large amounts of biomass, and it is able to extract considerable amounts of salt from contaminated soils (Leal et al. 2008, Souza 2010).

Saltbush is a species with C4 metabolism that naturally occurs in saline soils in the semiarid region of Australia. The species has been established in cattle grazing soils affected by salts (Barrett-Lennard et al. 2003). The plant was introduced in the Northeast region of Brazil in the 1930s, through research, due

1. Manuscript received in Nov./2015 and accepted for publication in Mar./2016 (http://dx.doi.org/10.1590/1983-40632016v4638719).

2. Universidade Federal de Sergipe, Centro de Ciências Agrárias, São Cristóvão, SE, Brazil. E-mails: 1fg.ufs@gmail.com, ratinhojlf@yahoo.com.br, prgagli@yahoo.com, lucasfmoliveira@gmail.com.

3. Universidade Estadual do Maranhão, Centro de Ciências Agrárias, Departamento de Engenharia Agronômica, São Luís, MA, Brazil.E-mail: fareoli@gmail.com. 
to its tolerance to saline and brackish soil, as well as to drought (Obras... 1938). Thus, it constitutes a useful plant for studying physiological mechanisms involved in salt stress resistance (Cabello-Hurtado \& Ramos 2004).

Salinity can inhibit plant growth by several factors in the short and long term. The shortterm effects include growth reduction, due to the osmotic effect of salt, which reduces cell expansion. Long-term effects include ionic stress, due to excessive salt absorption, leading to a reduction in the photosynthetic leaf area available for growth maintenance (Munns 2002). In both cases, growth reduction is often accompanied by low photosynthetic $\mathrm{CO}_{2}$ assimilation, due to stomatal and non-stomatal limitations, such as stomata closure and metabolism reduction caused by stress (Silva et al. 2008). However, regardless of the limitation, salinity can still alter stomatal conductance, transpiration, $\mathrm{CO}_{2}$ availability in the absorption sites in the chloroplast, and photosynthetic pigments (Parida \& Das 2005).

An important factor in the salt tolerance mechanism is the ability of plant cells to osmotically adjust themselves by accumulating organic solutes, such as proteins, sugars, free amino acids, proline, etc. (Munns 2002). Among these solutes, proline is an amino acid that protects cells from denaturation processes under conditions of salt stress, assisting in cellular ionic homeostasis, photosynthesis preservation, proteins and membranes stabilization, and free radicals removal (Azevedo Neto et al. 2009).

Given its halophyte nature and importance for soil remediation, and as a potential fodder crop for semiarid regions, this study aimed at evaluating the ecophysiological responses of saltbush plants under increasing $\mathrm{NaCl}$ levels over time.

\section{MATERIAL AND METHODS}

The experiment was carried out in a climatized greenhouse, with average temperature of $29{ }^{\circ} \mathrm{C}$ and relative humidity of $80 \%$, at the Universidade Federal de Sergipe, in São Cristóvão, Sergipe State, Brazil, in August 2013.

Forty days old saltbush plants were placed in $4 \mathrm{~L}$ polypropylene vessels (one plant per pot and five pots for each solution) filled with about $3.80 \mathrm{~kg}$ of soil, which was collected at 0.0-0.20 m depth, from a dystrophic Red Ultisol. Its chemical characterization was carried out at the Soil Analysis Laboratory of the Universidade Federal de Lavras, as it follows: phosphorus: $5.4 \mathrm{mg} \mathrm{dm}^{-3}$; potassium: $76.00 \mathrm{mg} \mathrm{dm}^{-3}$; exchangeable calcium: $14.18 \mathrm{cmol}_{\mathrm{c}} \mathrm{dm}^{-3}$; exchangeable magnesium: $10.85 \mathrm{cmol}_{\mathrm{c}} \mathrm{dm}^{-3}$; exchangeable

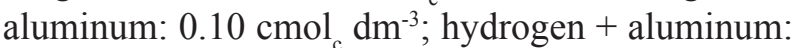
$7.87 \mathrm{cmol}_{\mathrm{c}} \mathrm{dm}^{-3}$; $\mathrm{pH}: 4.9$; organic matter: $3.14 \mathrm{dag} \mathrm{kg}^{-1}$; sum of exchangeable bases: $25.22 \mathrm{cmol}_{\mathrm{c}} \mathrm{dm}^{-3}$; cation exchange capacity: $33.09 \mathrm{cmol}_{\mathrm{c}} \mathrm{dm}^{-3}$; base saturation: $76.23 \mathrm{cmol}_{\mathrm{c}} \mathrm{dm}^{-3}$. Fertilization was carried out at the time of plants transplantation with $1.39 \mathrm{~g}$ of urea, $3.13 \mathrm{~g}$ of superphosphate and $1.08 \mathrm{~g}$ of potassium chloride per pot.

During 45 days, the same volume of saline concentration specific for each treatment $(0 \mathrm{mM}$, $150 \mathrm{mM}, 300 \mathrm{mM}, 450 \mathrm{mM}$ and $600 \mathrm{mM}$ of $\mathrm{NaCl}$ ) was added to keep the soil at field capacity. Mean values for electric conductivity (at $25{ }^{\circ} \mathrm{C}$ ) of the irrigation solutions were $0.0075 \mathrm{mS} \mathrm{cm}^{-1}$, $12.11 \mathrm{mS} \mathrm{cm}^{-1}, 16.36 \mathrm{mS} \mathrm{cm}{ }^{-1}, 22.1 \mathrm{mS} \mathrm{cm}^{-1}$ and $28.5 \mathrm{mS} \mathrm{cm}^{-1}$, respectively.

Treatments were arranged in a completely randomized design, in a $5 \times 4$ factorial scheme, with five salinity levels ( $0 \mathrm{mM}, 150 \mathrm{mM}, 300 \mathrm{mM}$, $450 \mathrm{mM}$ and $600 \mathrm{mM}$ of $\mathrm{NaCl})$ and four periods of evaluation over time $(0,15,30$ and 45 days after the application of treatments), with five replications.

Every two weeks, plant height and stem diameter were measured, using a graduated ruler and a digital caliper. Leaves from the upper third of the plants were also sampled for the determination of free proline (Bates et al. 1973).

Gas exchange was measured using the infrared gas analyzer IRGA (LI-6400xt model, LI-COR, Nebrasca, USA), with $300 \mathrm{~mL} \mathrm{~min}^{-1}$ air flow and 1,500 $\mu \mathrm{mol} \mathrm{m}^{-2} \mathrm{~s}^{-1}$ coupled light source, on fully expanded leaves of the upper third part of the seedlings. Measurements were carried out every two weeks, between 8 am and 9 am, under room relative humidity and air temperature. The obtained gas exchange data were: photosynthetic $\mathrm{CO}_{2}$ assimilation, stomatal conductance, instantaneous transpiration, vapor pressure deficit between leaf and air and carbon internal concentration.

For the determination of leaf chlorophyll $a, b$ and total, a non-destructive method was used, with a Clorofilog chlorophyll meter (CFL 1030 model, Falker, Porto Alegre, BR). Measurements were carried out at the end of the gas exchange analysis, in the middle portion of the leaf, located in the upper third of the seedlings. Data were subjected to analysis of 
variance by the $\mathrm{F}$ test and to regression analysis. Data analyses were carried out with Sisvar (Ferreira 2000).

\section{RESULTS AND DISCUSSION}

Plant height growth was affected by increasing $\mathrm{NaCl}$ levels during the irrigation (Figure 1a). The $0 \mathrm{mM}, 150 \mathrm{mM}$ and $300 \mathrm{mM}$ doses of $\mathrm{NaCl}$ resulted in higher regression coefficients (slope), when compared to the higher doses $(450 \mathrm{mM}$ and $600 \mathrm{mM}$ ), with relative height increases of $38.41 \%$, $29.69 \%$ and $24.63 \%$, respectively, if compared to the beginning of the experiment.

Stem diameter also increased over time for all $\mathrm{NaCl}$ levels (Figure 1b), with increments of $72.64 \%, 69.39 \%$ and $70.96 \%$, respectively for levels of $0 \mathrm{mM}, 150 \mathrm{mM}$ and $300 \mathrm{mM}$ of $\mathrm{NaCl}$. Plants subjected to $450 \mathrm{mM}$ and $600 \mathrm{mM}$ of $\mathrm{NaCl}$ also followed the same trend, showing that salt stress did not affect stem diameter as much as height. However, under higher salt concentrations $(450 \mathrm{mM}$ and $600 \mathrm{mM}$ of $\mathrm{NaCl}$ ), stem diameters presented the lowest average values in the whole experimental interval. In general, this behavior proves that the species has adjustment or resistance mechanism to the salinity condition imposed, which may have influenced plants to keep plant cell expansion. Thus, the limited growth of plants subjected to high levels of electric conductivity may be predominantly due to osmotic stress (Munns et al. 2006).

Araújo et al. (2006), studying $A$. nummularia plants grown under increasing $\mathrm{NaCl}$ levels, reported growth stimulation as the concentration of $\mathrm{Na}^{+}$and $\mathrm{Cl}^{-}$ions to $300 \mathrm{mmol} \mathrm{L}^{-1}$ in the irrigation solution increased. These authors observed that above this concentration level, growth is negatively affected due to disruption of plant metabolism, with a subsequent reduction in growth. Bazihizina et al. (2012) evaluated the growth of $A$. nummularia under $10 \mathrm{mM}, 120 \mathrm{mM}, 230 \mathrm{mM}, 450 \mathrm{mM}$ and $670 \mathrm{mM}$ of $\mathrm{NaCl}$ and observed, 21 days later, an increase in growth at the interval of $120-230 \mathrm{~mm}$ of $\mathrm{NaCl}$. However, at $450 \mathrm{mM}$, growth was similar to that of plants exposed to $10 \mathrm{mM}$ of $\mathrm{NaCl}$. At $600 \mathrm{mM}$, there was a $71 \%$ reduction in the stem growth rate, in relation to the $\mathrm{NaCl}$ dose of $10 \mathrm{mM}$.

Photosynthetic $\mathrm{CO}_{2}$ assimilation (Figure 2a) for all the salinity levels decreased immediately after the treatment, and then increased with time under salt stress imposition, reaching minimum values of $12.84 \mu \mathrm{mol} \mathrm{m}^{-2} \mathrm{~s}^{-1}, 6.07 \mu \mathrm{mol} \mathrm{m} \mathrm{m}^{-2} \mathrm{~s}^{-1}, 3.28 \mu \mathrm{mol} \mathrm{m}^{-2} \mathrm{~s}^{-1}$, $6.30 \mu \mathrm{mol} \mathrm{m} \mathrm{m}^{-2} \mathrm{~s}^{-1}$ and $2.49 \mu \mathrm{mol} \mathrm{m} \mathrm{m}^{-2} \mathrm{~s}^{-1}$, respectively for the levels of $0 \mathrm{mM}, 150 \mathrm{mM}, 300 \mathrm{mM}, 450 \mathrm{mM}$ and $600 \mathrm{mM}$ of $\mathrm{NaCl}$. There was little variation in the time of maximum inflection of photosynthetic $\mathrm{CO}_{2}$ assimilation curve for salinity, reaching a minimum at 22-24 days for all the salt treatments. After this period, the photosynthesis rate increases, reaching average values close to those obtained in the stress-free period at 45 days under stress, demonstrating high capacity of adaptation to the conditions of this study.

Stomatal conductance showed greater variation among the different salinity levels. However, similarly to photosynthetic $\mathrm{CO}_{2}$ assimilation, it also showed a slight upward trend for all $\mathrm{NaCl}$ levels (Figure 2b). For the levels of $450 \mathrm{mM}$ and $600 \mathrm{mM}$, this increase was linear $(\mathrm{p}<0.01)$, whereas, for the levels of $150 \mathrm{mM}$ and $300 \mathrm{mM}$, effects of the time under salt stress imposition were quadratic $(p<0.01)$. Mean values obtained at 45 days for the
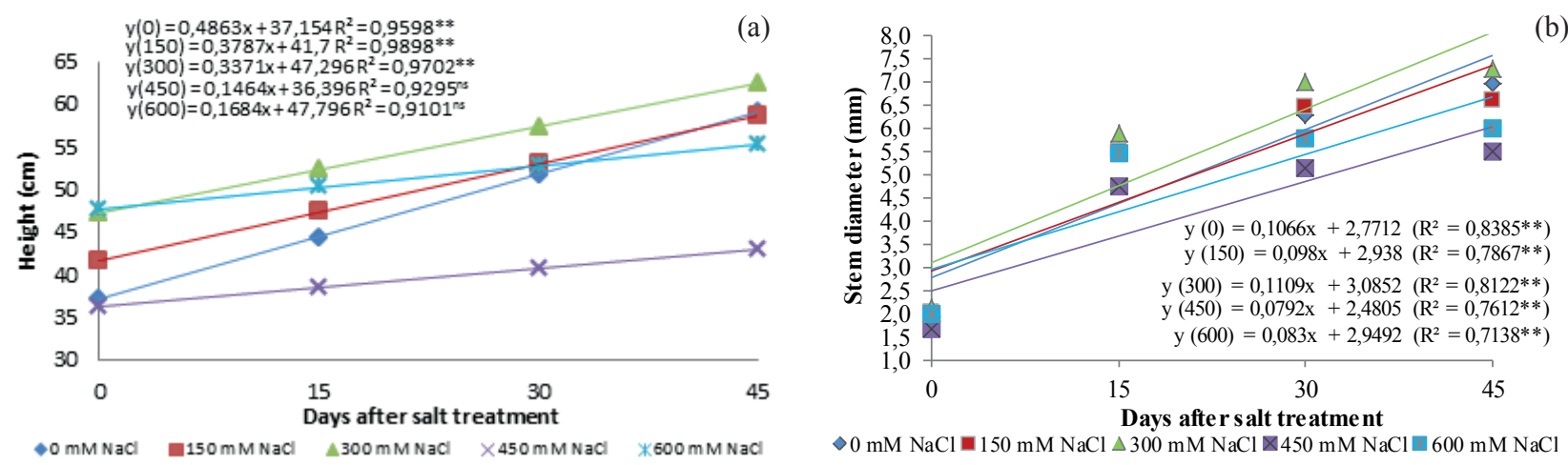

Figure 1. Plant height (a) and stem diameter (b) of saltbush plants grown under different $\mathrm{NaCl}$ levels, as a function of the time under salt stress imposition (days). *** and ${ }^{\text {ns: }}$ significant at $5 \%$ and $1 \%$ and not significant, respectively. 
levels of $300 \mathrm{mM}, 450 \mathrm{mM}$ and $600 \mathrm{mM}$ of $\mathrm{NaCl}$ were respectively $0.41 \mathrm{~mol} \mathrm{~m}^{-2} \mathrm{~s}^{-1}, 0.53 \mathrm{~mol} \mathrm{~m}^{-2} \mathrm{~s}^{-1}$ and $0.83 \mathrm{~mol} \mathrm{~m}^{-2} \mathrm{~s}^{-1}$.

Responses of these two variables show that saltbush plants did not keep their stomata predominantly closed. This behavior suggests a possible adaptation of the plants to maintain favorable photosynthetic assimilation, even under higher salinity levels, when there are limitations in water absorption. Studies have shown that plants of the Atriplex genus subjected to salinity decreased photosynthetic $\mathrm{CO}_{2}$ assimilation due to reduced stomatal conductance (Hassine et al. 2008, Bazihizina et al. 2009).
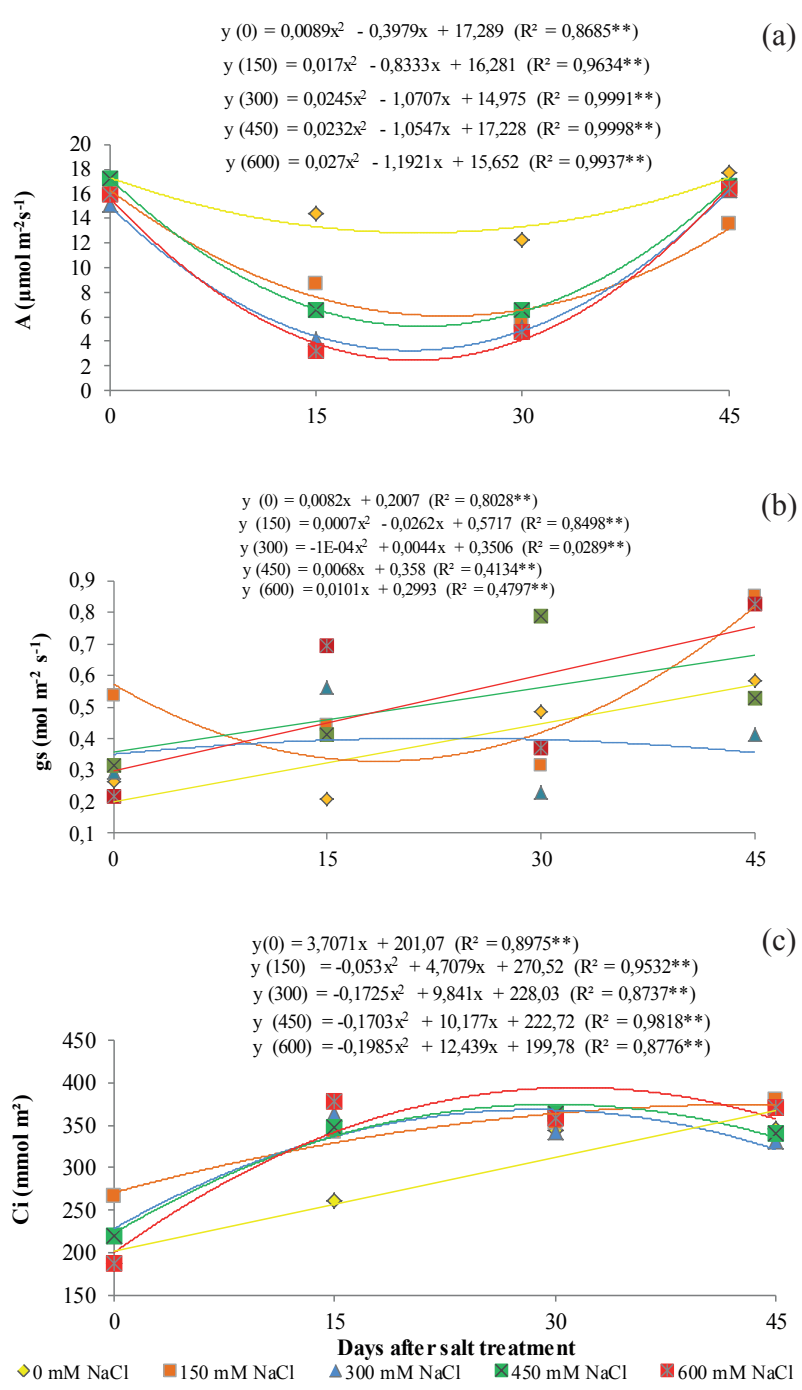

Stomatal response usually occurs before photosynthesis inhibition, and limits $\mathrm{CO}_{2}$ availability in the chloroplast. This defense mechanism is probably the most important factor limiting carbon fixation. However, non-stomatal photosynthesis limitations have been attributed to the reduction in carboxylation efficiency, which may be caused by the accumulation of salts in the mesophyll, resulting in changes in the intracellular $\mathrm{CO}_{2}$ concentration (Larcher 2004).

$\mathrm{CO}_{2}$ internal concentration $(\mathrm{Ci})$ presented quadratic response $(\mathrm{p}<0.01)$ to all $\mathrm{NaCl}$ levels over time (Figure 2c), except at the concentration 0 (linear), with upward trend until the 45 th, 45 th, 29th, 30th and 31st day, respectively for concentrations of $0 \mathrm{mM}, 150 \mathrm{mM}, 300 \mathrm{mM}$, $450 \mathrm{mM}$ and $600 \mathrm{mM}$ of $\mathrm{NaCl}$. The maximum $\mathrm{CO}_{2}$ internal concentration values were $350.38 \mathrm{mmol} \mathrm{m}^{-2}$, $375.06 \mathrm{mmol} \mathrm{m}^{-2}, 368.35 \mathrm{mmol} \mathrm{m}^{-2}, 374.76 \mathrm{mmol} \mathrm{m}^{-2}$ and $394.63 \mathrm{mmol} \mathrm{m}^{-2}$. After this increase, mean values did not change much until the last evaluation period. The decrease in $\mathrm{CO}_{2}$ assimilation coincided with the increase in $\mathrm{Ci}$, demonstrating that it may

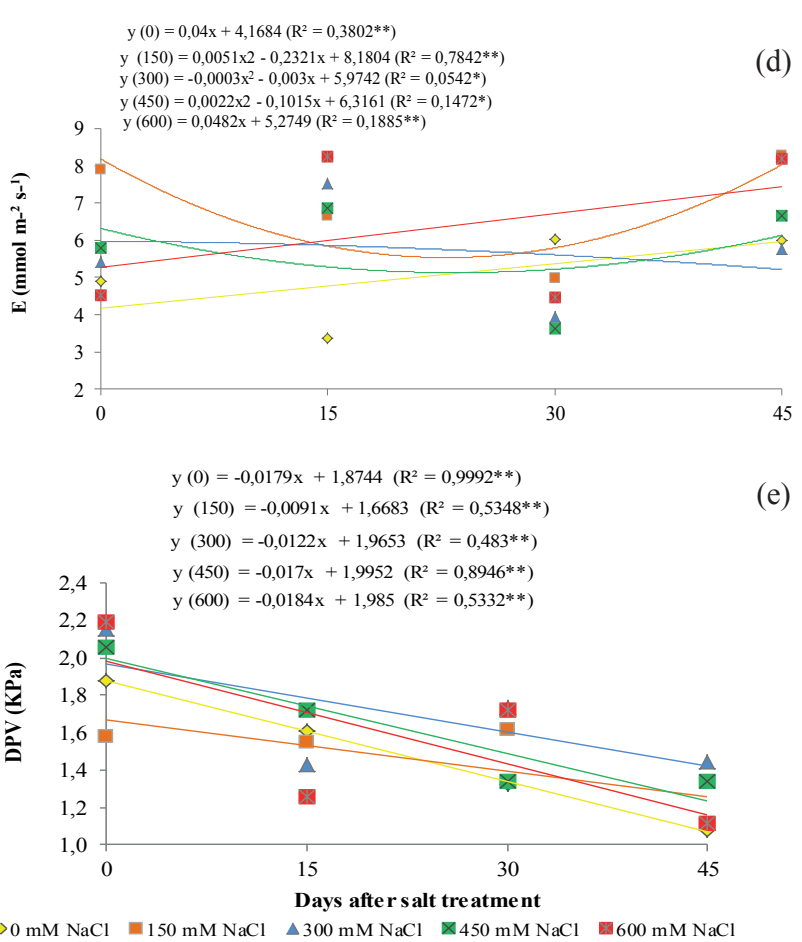

Figure 2. Photosynthetic $\mathrm{CO}_{2}$ assimilation (A) (a), stomatal conductance (gS) (b), internal carbon concentration (Ci) (c), transpiration (E) (d) and vapor pressure deficit between leaf and air (VPDleaf-air) (e) of saltbush plants under different $\mathrm{NaCl}$ levels, as a function of the time under salt stress imposition (days). *, ** and ${ }^{\text {ns. }}$ : significant at $5 \%$ and $1 \%$ and not significant, respectively. 
have occurred inhibition of photosynthetic carbon fixation. This may be due to a non-stomatal response, such as ionic damages on the photosynthetic apparatus. However, the small variation of $\mathrm{Ci}$ values in the last periods is consistent with the maintenance of photosynthetic $\mathrm{CO}_{2}$ assimilation until the last day of evaluation, which may be caused by the period of adaptation to the imposed stress.

According to Machado et al. (2009), Ci reflects the substrate available for photosynthesis, and may indicate whether the stomatal closure is restricting the photosynthetic activity or not. Therefore, decreases in $\mathrm{Ci}$ could reduce photosynthetic assimilation due to the reduction of $\mathrm{CO}_{2}$ concentration for rubisco activity. However, lower $\mathrm{Ci}$ values also stimulate the opening of the stomata, allowing increased inflow of $\mathrm{CO}_{2}$ for the substomatal cavity, which tends to a balance between $\mathrm{CO}_{2}$ intake and exhaust, maintaining $\mathrm{Ci}$ approximately constant.

Transpiration, as well as stomatal conductance, was significantly influenced by salinity levels, showing a slight trend to increase (Figure 2d). Transpiration followed quadratic response models for levels of $150 \mathrm{mM}$ and $450 \mathrm{mM}$ of $\mathrm{NaCl}$, with a slight increase from the 30th day $(\mathrm{p}<0.01)$. Moreover, levels of $300 \mathrm{mM}$ and $600 \mathrm{mM}$ of $\mathrm{NaCl}$ showed linear and quadratic response $(\mathrm{p}<0.01)$, respectively. Therefore, it can be inferred that saline treatments did not cause severe stress in plants. Salts might have stimulated the stomata opening, increasing transpiration in some of the treatments. Thus, salt excess caused by the application of saline solutions may have promoted an increase in plant transpiration, due to decreases in the osmotic potential of the soil. According to Chen \& Jiang (2010), this fact can be explained by the need for more energy from the plant, such as in the osmotic adjustment, in order to generate more negative potential, than that found in the soil, for water absorption. Such energy expenditure involves more transpiration by the plant, as soil salinity increases up to a certain point. From this point, the plant may dehydrate.

The vapor pressure deficit between leaf and air $\left(\mathrm{VPD}_{\text {leaf-air }}\right)$ showed a linear decrease trend $(\mathrm{p}<0.01)$ for all salinity levels over time (Figure 2e). At 45 days, mean values of $1.44 \mathrm{KPa}, 1.34 \mathrm{KPa}$ and $1.12 \mathrm{KPa}$ were observed respectively for levels of $300 \mathrm{mM}, 450 \mathrm{mM}$ and $600 \mathrm{mM}$ of $\mathrm{NaCl}$. It has been found that the increase in $\mathrm{VPD}_{\text {leaf-air }}$, when the plant is under water/salt stress, reduces the water vapor flow in the substomatal chamber to the atmosphere, causing reduction in the stomatal conductance and transpiration (Thomas \& Gausling 2000). However, in the present study, the reduction in $\mathrm{VPD}_{\text {leaf-air }}$ along the time under salt stress imposition seems to have favored saltbush plants to maintain small stomatal opening and transpiration rates at levels consistent with the salinity conditions to which they were exposed. Chlorophyll $a$ and $b$ contents, as well as their relative contents (Chlor a/Chlor b ratio), at all $\mathrm{NaCl}$ levels, did not differ $(\mathrm{p}>0.05)$ over time, indicating that chlorophyll is not affected by salt concentration.

The salinity effect on proline content over time was significant $(p<0.01)$, resulting in a linear increase. The highest contents were found at 45 days, for the levels of $450 \mathrm{mM}$ and $600 \mathrm{mM}$ of $\mathrm{NaCl}$, respectively with $3.44 \mu \mathrm{mol} \mathrm{g}^{-1}$ and $3.01 \mu \mathrm{mol} \mathrm{g}^{-1}$ of fresh matter (Figure 3). Therefore, saltbush plants responded to salinity by maintaining larger proline concentrations. This accumulation can be considered a physiological indicator of response to salt stress.

Plants subjected to increasing $\mathrm{NaCl}$ levels in the irrigation solution had a progressive proline accumulation (Hussin et al. 2012). The highest salt treatment $(750 \mathrm{mM}$ of $\mathrm{NaCl})$ resulted in a significant increase (six and eight times) of proline in the saltbush leaves. The increase in proline content with the increase in salinity and in salt exposure time suggests a protective role of proline against water loss and/or reactive oxygen species. Proline generates a solute concentration gradient to lower the osmotic potential of cells, helping them to avoid water loss by osmosis. Proline also aids free radicals removal, helping plants to cope with ionic stress (Azevedo Neto et al. 2009).

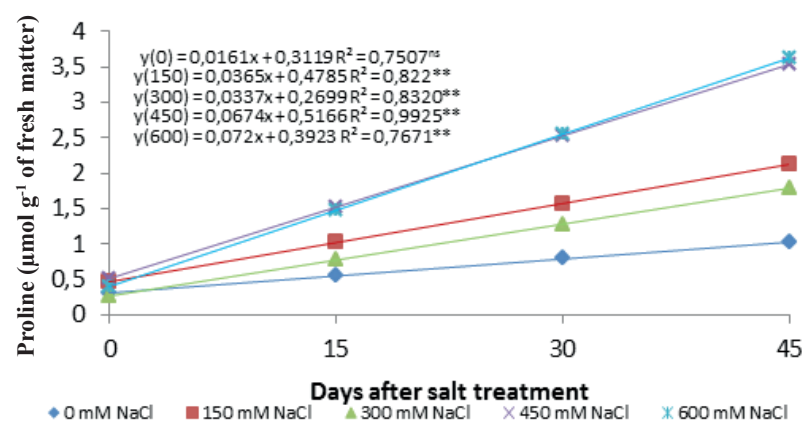

Figure 3. Proline content in saltbush plants under different $\mathrm{NaCl}$ levels, as a function of salt stress imposition time (days). *, ${ }^{* *}$ and ${ }^{\mathrm{ns}}$ : significant at $5 \%$ and $1 \%$ and not significant, respectively. 


\section{CONCLUSIONS}

1. Atriplex nummularia can grow under salt stress, with its growth being affected only at higher concentrations ( $>600 \mathrm{mM}$ of $\mathrm{NaCl}$ ).

2. Ecophysiological parameters are little affected by salt concentration. Both photosynthetic $\mathrm{CO}_{2}$ assimilation and stomatal conductance showed adaptive capacity to salinity, avoiding stomatal closure and reduction in the photosynthetic rate at 45 days.

3. Chlorophyll $a$ and $b$ contents remained virtually stable in function of time, under salt stress imposition.

4. The proline content increases with the time after stress imposition and with higher salinity levels.

\section{REFERENCES}

ARAÚJO, S. A. M. et al. Salinity tolerance of halophyte Atriplex nummularia L. grown under increasing $\mathrm{NaCl}$ levels. Revista Brasileira de Engenharia Agrícola e Ambiental, v. 10, n. 4, p. 848-854, 2006.

AZEVEDO NETO, A. D.; PRISCO, J. T.; GOMESFILHO, E. Changes in soluble amino-N, soluble proteins and free amino acids in leaves and roots of salt-stressed maize genotypes. Journal of Plant Interactions, v. 4, n. 1, p. 137-144, 2009.

BARRETT-LENNARD, E. G.; MALCOLM, C. V.; BATHGATE, A. Saltland pastures in Australia: a practical guide. 2. ed. Canberra: ACT, 2003.

BATES, L. S.; WALDRAN, R. P.; TEARE, I. D. Rapid determination of free proline for water stress studies. Plant and Soil, v. 39, n. 1, p. 205-208, 1973.

BAZIHIZINA, N.; BARRETT-LENNARD, E. G.; COLMER, T. D. Plant responses to heterogeneous salinity: growth of the halophyte Atriplex nummularia is determined by the root-weighted mean salinity of the root zone. Journal of Experimental Botany, v. 63, n. 1, p. 6347-6358, 2012.

BAZIHIZINA, N.; COLMER, T. D.; BARRETTLENNARD, E. G. Response to non-uniform salinity in the root zone of the halophyte Atriplex nummularia: growth, photosynthesis, water relations and tissue ion concentrations. Annals of Botany, v. 104, n. 1, p. 737745, 2009.

CABELLO-HURTADO, F.; RAMOS, J. Isolation and functional analysis of the glycerol permease activity of two new nodulin-like intrinsic proteins from salt stressed roots of the halophyte Atriplex nummularia. Plant Science, v. 166, n. 1, p. 633-640, 2004.

CHEN, H.; JIANG, J. Osmotic adjustment and plant adaptation to environmental changes related to drought and salinity. Environmental Reviews, v. 18, n. 1, p. 309319, 2010.

FERREIRA, D. F. Sisvar: system analysis of variance. Lavras: UFLa, 2000.

HASSINE, A. B. et al. An inland and a coastal population of the Mediterranean xero-halophyte species Atriplex halimus L. differ in their ability to accumulate proline and glycinebetaine in response to salinity and water stress. Journal of Experimental Botany, v. 59, n. 6, p. 1315-1326, 2008.

HUSSIN, S.; GEISSLER, N.; KOYRO, H. W. Effect of $\mathrm{NaCl}$ salinity on Atriplex nummularia (L.) with special emphasis on carbon and nitrogen metabolism. Acta Physiologiae Plantarum, v. 35, n. 1, p. 1025-1038, 2012.

LARCHER, W. Ecofisiologia vegetal. 3. ed. São Carlos: RiMa, 2004.

LEAL, I. G. et al. Fitorremediação de solo salino sódico por Atriplex nummularia e gesso de jazida. Revista Brasileira de Ciência do Solo, v. 32, n. 3, p. 1065-1072, 2008.

MACHADO, R. S. et al. Respostas biométricas e fisiológicas ao déficit hídrico em cana-de-açúcar em diferentes fases fenológicas. Pesquisa Agropecuária Brasileira, v. 44, n. 12, p. 1575-1582, 2009.

MUNNS, R. Comparative physiology of salt and water stress. Plant, Cell and Environment, v. 25, n. 5, p. 659662, 2002.

MUNNS, R.; JAMES, R. A.; LAUCHLI, A. Approaches to increasing the salt tolerance of wheat and other cereals. Journal of Experimental Botany, v. 57, n. 1, p. 1025-1043, 2006.

OBRAS contra as secas: objetivos, programas, ação da inspetoria, resultados. Boletim da Inspetoria Federal de Obras Contra as Secas, v. 10, n. 2, p. 157-197, 1938.

PARIDA, A. K.; DAS, A. B. Salt tolerance and salinity effects on plants: a review. Ecotoxicology and Environmental Safety, v. 60, n. 1, p. 324-349, 2005.

PORTO, E. R. et al. Uso da erva-sal (Atriplex nummularia) como forrageira irrigada com água salina. Petrolina: Embrapa Semiárido, 2000.

SILVA, E. C. et al. Physiological responses to salt stress in young umbu plants. Environmental and Experimental Botany, v. 63, n. 1, p. 147-157, 2008. 
SOUZA, E. R. de. Fitorremediação de Neossolo Flúvico salino sódico de Pernambuco com Atriplex nummularia. 2010. 68 f. Tese (Doutorado em Ciência do Solo) Universidade Federal Rural de Pernambuco, Recife, 2010.

SOUZA, L. C.; QUEIROZ, J. E.; GHEYI, H. R. Variabilidade espacial da salinidade de um solo aluvial no semiárido paraibano. Revista Brasileira de Engenharia
Agrícola e Ambiental, Campina Grande, v. 4, n. 1, p. 3540, 2000.

TAIZ, L.; ZEIGER, E. Fisiologia vegetal. 5. ed. Porto Alegre: Artmed, 2013.

THOMAS, F. M.; GAUSLING, T. Morphological and physiological responses of oak seedlings (Quercus petraea and Quercus robur) to moderate drought. Annals of Forest Science, v. 57, n. 1, p. 325-333, 2000. 